malarial patient, was involvod in the transmission of malaria. This discovery, mado after dissecting more than a thousand mosquitoes, solved a mystery that had baffled all previous workers, and gave mankind the means of preventing malaria through mosquito control. On the day following this brilliant achievement, Ross wrote his hymn of praiso boginning "Before Thy Feet I fall", now included in many hymnals. The hymn was sung by the crowded congregation which assembled at the service on Monday, after Mr. Masefield had delivered his address. He referred to Ross as a man of science through whose investigations many places on the earth, in which white men could formorly scarcely hope to survive, had become tropical health rosorts, and ho paid striking testimony to Ross's genius also in tho provinces of poetry, art, music and mathematics. Some of Ross's verses were afterwards read by Mrs. Dale Roberts and Miss Judith Masefield. The selections included extracts from "In Hxile" and "The Monsoon", and the poems "India", "Thought and Action", "Indian Fevers", "The Star" and "Petition".

\section{Determinations of the Speed of Light}

A Central News messago from New York states that a woll defined periodic variation in the speed of light has been registered in the experiments now being carried out at Mount Wilson which were begun by Michelson. The message refers to a passage in the annual report of the director of the Mount Wilson Observatory, which was received in Great Britain some time ago. As is well known, Michelson found that atmospheric irregularities, the astronomer's 'bad seeing', interfered with his attempts to dotermine the velocity of light using long bases, from Mount Wilson to neighbouring peaks. Ho was led to tho heroic task of constructing a vacuurn base a mile long, and a tunnel of thirty-six inch diameter and a mile long was constructed. It is so well made that a vacuum of two or three millimetres of mercury can be maintained in it. The last report stated that it was hoped to conclude the work in August, so that we may hope for full details before very long. The periodic term that the report mentions is presumably of a purely instrumental character. Our readors will remember that it has sometimes been urged that the precise observations of the velocity of light which have been made from time to time do show a definite secular change of the velocity (see, for example, Ghenry de Bray, Nature, 120, 602, Oct. 22, 1927, and 127, 522, April 4, 1931), but the viow has so far found little support from men of science generally.

\section{New Department in the British Museum}

AN important change in the organisation of the British Museum collections is announced. A now department has been constituted under the name of the Department of Oriental Antiquities and of Ethnography, which will combine parts of the Department of Ceramics and Ethnography and of Prints and Drawings. The existing Department of Ceramics and Ethnography, as such, will cease to exist. The othnographical collections henceforth will form a sub-section of the new department. This will also include antiquities and objects of art from the Near, Middle, and Far East, as well as India (in so far as these are not already included under the Department of Assyrian and Egyptian Antiquities or the Greek and Roman Department), and with them will be shown the oriental paintings, prints and drawings now included as a sub-department in the Department of Prints and Drawings. Mr. R. L. Hobson, keeper of the Dopartment of Coramics and Ethnography, will be keeper of the new department, with Capt. T. A. Joyce as deputy keeper, in charge of the sub. departmont of ethnography. For many reasons the innovation will be wolcomed. The separation of oriental paintings and drawings from cthor forms of oriental art has been an anomaly ever since they ceased to be tho mere hobby of the dilettante collector, and became the subject of serious scientific study. It should be realised that the constitution of a new department can be regarded as really progressive only in so far as it is impermanent-a stage towards the formation of a comprehensive collection of oriental art and antiquitios, fittingly housed and adequately displayed-and ethnography is viewed on a scale of values which makes of it something more than a sub-section of part of its own subject-matter.

\section{Man and the Machine}

IN an address to the World Federation of Educa. tional Associations at Dublin on "The Craftsman and the Changing World", Mr. J. Wickham Murray gave a brilliant picture of the modern world, indicating the extent to which we have passed from a nonscientific age to a scientific age, from a manual age to an ago dominated by tho machine. That domination has not only affected the life of tho individual, impairing, for example, his power of making a quiet judgment, but also has vast social consequences such as those frequently referred to by the term 'techno. logical unemployment'. Despite the now industries created by science the growth of mechanical power is continually displacing men and women. To suggest even in these conditions that a return to handicraft is required is to miss the significance of the machine age. Mr. Murray suggested that the only remedy is a couragoous attempt to obtain control of the machine, believing that by its controlled dovelopment the standard of life might be indefinitely oxtonded. Craftsmanship should not be in competition with the industrial world but in complement with it, assisting it to secure the ability to mako firm, wise, far-seeing and unhurriod judgments. Mr. Murray believes it should be the duty of the craftsman to inspire and teach the oconomic and industrial world and emphasises the kinship between art and craftsmanship. The influence of the craftsman in this way offers our civilisation its best hope of regaining the capacity for thought and judgment, and the poise of which the turmoil and superficiality and distress of the machine ane tend to rob us.

\section{A Pest of Tobacco}

THE somowhat sudden appearance of a new tobacco pest, Ephestia elutella, in the British Isles 